\title{
MELAKSANAKAN PENDAMPINGAN BERBASIS KKG BAGI GURU KELAS SD NEGERI 12 AMPENAN SEMESTER DUA TAHUN PELAJARAN 2018/2019 UPAYA MENINGKATKAN KOMPETENSI GURU DALAM PENYUSUNAN RENCANA PELAKSANAAN PEMBELAJARAN (RPP)
}

\author{
Sarbini \\ SD Negeri 12 Ampenan.
}

\begin{abstract}
Abstrak. Latar belakang diadakannya Penelitian ini adalah rendahnya kompetensi guru sasaran Di SD Negeri 12 Ampenan dalam penyusunan Rencana Pelakssanaan Pembelajaran (RPP) yang baik dan benar yang berdampak kurang percaya diri dalam proses pembelajaran. Solusinya diadakan pendampingan baik secara kelompok maupun individu dalam penyusunan RPP yang baik dan benar. Tujuannya adalah untuk mengetahui efektifitas pelaksanaan pendampingan berbasis KKG dalam upaya meningkatkan kompetensi guru dalam menyusun RPP yang baik dan benar, yang bermanfaat untuk meningkatkan profesionalisme sebagai kepala sekolah dan bagi guru untuk meningkatkan proses pembelajaran di kelas. Hipotesis tindakan: meningkatkan kompetensi guru guru sasaran SD Negeri 12 Ampenan semester satu tahun pelajaran 2018/2019 dalam menyusun RPP yang baik dan benar. Penelitian ini dilaksanakan sebanyak dua siklus, masing-masing siklus satu kali pertemuan. Tahapan setiap siklus adalah perencanaan, pelaksanaan, pengamatan, dan refleksi. Indikator keberhasilan dalam penelitian ini adalah; 1) hasil observasi Kepala Sekolah maupun observasi guru selama proses pendampingan telah memperoleh skor rata-rata $\geq 4,0,2$ ) hasil kerja guru dalam penyusunan RPP mencapai $\geq 85 \%$ dengan nilai rata-rata $\geq 80,00$. Hasil penelitian pada siklus I observasi Kepala Sekolah rata-rata $(3,40)$, observasi guru rata-rata $(3,33)$ dan hasil kerja individual rata-rata nilai $(67,40)$ dengan prosentase ketercapaian $(0 \%)$. Pada siklus II observasi Kepala Sekolah rata-rata $(4,50)$, observasi guru rata-rata $(4,67)$ dan hasil kerja individual rata-rata nilai $(87,37)$ dengan prosentase ketercapaian $(100 \%)$. Indikator keberhasilan telah tercapai, penelitian di nyatakan berhasil dan dihentikan pada siklus II. Kesimpulan; pelaksanaan pendampingan dapat meningkatkan kompetensi guru sasaran SD Negeri 12 Ampenan dalam penyusunan RPP berdasarkan KTSP dan Kurikulum 2013. Disarankan agar Kepala Sekolah lainnya melakukan penelitian sejenis dalam upaya peningkatan kompetensi guru, dan kepada guru mata pelajaran agar mampu menyusun RPP yang baik dan benar.
\end{abstract}

Kata Kunci : Pendampingan - RPP

\section{PENDAHULUAN}

\section{Latar Belakang}

Pada hakikatnya penyusunan RPP bertujuan merancang pengalaman belajar peserta didik untuk mencapai tujuan pembelajaran. Belum ada alur pikir yang spesifik untuk menyusun RPP, karena rancangan tersebut seharusnya kaya akan inovasi sesuai dengan spesifikasi materi ajar dan lingkungan belajar peserta didik yang meliputi sumber daya alam dan sumber daya local, kebutuhan masyarakat, serta perkembangan ilmu pengetahuan dan teknologi. Rencana Pelaksanaan Pembelajaran (RPP) yang dibuat oleh guru selama ini patut diduga guru tidak melakukan penghayatan terhadap jiwa profesi pendidik. Keadaan ini dapat dipahami karena guru terbiasa menerima barang-barang dalam bentuk format yang mengekang guru untuk berinovasi dalam penyiapan RPP yang cenderung bersifat formalitas. Bukan menjadi komponen utama sebagai acuan dalam proses pembelajaran sehingga ketika otonomi pendidikan dilayangkan tak seorang guru pun mempercayainya.

Di SD Negeri 12 Ampenan pada tahun pelajaran 2018/2019 masih menggunakan kurikulum yaitu Kurikulum Tingkat Satuan Pendidikan (KTSP) dan Kurikulum 2013. Dalam penyusunan Rencana Pelaksanaan Pembelajaran (RPP) masingmasing guru belum seragam, karena memberlakukan dua kurikulum. Kepala 
sekolah sudah melaksanakan pendampingan bagi guru kelas maupun guru mata pelajaran/bidang studi, akan tetapi hasilnya masih belum optimal. Hal ini dapat dibuktikan bahwa pada umumnya guru memiliki RPP bukan buatan sendiri, kecendrungan: 1) meminjam dari guru sekolah lain yang kondisi peserta didiknya tidak setara sehingga sehingga RPP tidak tepat untuk diterapkan di sekolah, 2) copy paste di internet tanpa di addaptasi, yang penting ketika ditanya kepala sekolah dan atau pengawas sekolah sudah membuat, 3) menggunakan RPP yang diambil dari contoh RPP pada lembar kerja siswa (LKS) terbitan swasta yang kecendrungan kurang relevan dengan kurikulum yang berlaku.

Adapun faktor penyebab belum sempurnanya guru kelas SD Negeri 12 Ampenan dalam penyusunan RPP adalah: 1) guru belum pernah mendapatkan pendampingan secara khusus bagaimana menyusun RPP berdasarkan KTSP maupun berdasarkan kurikulum 2013, 2) setiap guru mengajukan RPP kepada kepala sekolah jarang sekali diteliti, kecendrungan langsung ditanda tangani, 3) guru masih jarang-jarang dipanggil untuk mengikuti pendidikan dan pelatihan (Diklat) terlebih-lebih yang materinya khusus pembimbingan tata cara penyusunan RPP, 4) guru mendapatkan RPP hanya minta tolong kepada operator sekolah untuk mendownloadkan dari internet tanpa diadaptasi/disesuaikan dengan situasi dan kondisi peserta didik di sekolahnya, 5) alas an klasik, guru beraalasan banyak jam mengajarnya sehingga tidak sempat untuk menyusun RPP, dan 6) kegiatan KKG disekolah kurang berjalan sebagaimana mestinya, kalaupun diadakan KKG tetapi kegiatannya hanya mengobrol saja, tidak pernah secara serius membicarakan tentang penyusunan RPP yang sesuai dengan KTSP maupun Kurikulum 2013.

Ada banyak solusi yang bisa dilakukan oleh kepala sekolah selaku peneliti dalam upaya meniingkatkan kompetensi guru kelas dalam penyusunan RPP berdasarkan KTSP dan Kurikulum 2013 diantaranya adalah dengan melaksanakan pendampingan berbasis KKG bagi guru kelas di SD Negeri 12 Ampenan semester Dua Tahun Pelajaran 2018/2019 upaya meningkatkan kompetensi guru dalam penyusunan RPP.

Adapun alasan riil melaksanakan pendampingan yaitu karena model pendampingan ini berdasarkan pengalaman peneliti mempunyai keunggulan bila dibandingkan dengan model yang lain. Keunggulaan model pendampingan ini adalah: a) mempermudah bagi peneliti untuk mengidentifikasi terhadap permassalahan guru dalam penyusunan RPP, b)mempermudah untuk menentukan solusi sesuai dengan karakteristik maasing-masing guru, c) mempererat hubungan/silaturrahmi antara peneliti dengan guru yang dibimbingnya, sehingga permasalahan yang ada dapat teratasi dengan bimbingan disesuaikan dengan karakter/kepribadian masing-massing guru, d) pekerjaan yang sulit bisa menjadi mudah karena pada saat pendampingan antara peneliti dan guru, guru dengan guru, yang lain bisa saling mengisi dan saling memberikan solusi atas dasar kesepakatan bersama, dan e) Kegiatan Kelompok Kerja Guru (KKG) di sekolah menjadi bermakna dan bermanfaat demi peningkatan mutu pendidikan di sekolah.

\section{Rumusan Masalah}

"Apakah pelaksanaan pendampingan berbasis KKG dapat meningkatkan kompetensi guru SD Negeri 12 Ampenan dalam penyusunan Rencana Pelaksanaan Pembelajaran (RPP) Semester Dua Tahun Pelajaran 2018/2019?"

\section{Tujuan Penelitian}

Adapun tujuan diadakannya Penelitian Tindakan Sekolah (PTS) ini adalah : "Untuk mengetahui efektifitas pelaksanaan pendampingan berbasis KKG dalam upaya meningkatkan kompetensi guru SD Negeri 12 Ampenan dalam penyusunan RPP"

\section{Manfaat Penelitian}

1. Bagi Kepala Sekolah

- Hasil penelitian ini sangat bermanfaat bagi kepala SD Negeri 12 Ampenan dalam melaksanakan pembinaan akademik guru kelas maupun guru bidang studi/mata pelajaran di sekolah 
binaannya, khususnya upaya meningkatkan kompetensi dalam penyusunan RPP.

- Bermanfaat untuk memenuhi syarat kenaikan pangkat/golongan ke jenjang yang lebih tinggi.

2. Bagi Guru

- Sangat bermanfaat dalam upaya meningkatkan kompetensi khususnya dalam penyusunan RPP, sehingga dalam proses pembelajaran semakin kondusif dan bisa mencapai hasil seperti diharapkan.

- Sangat bermanfaat dalam upayamenjadi guru yang profesional yang mampu membelajarkan peserta didik yang aktif, kreatif, efektif, dan menyenangkan.

\section{KAJIAN PUSTAKA \\ Kerangka Teoritis \\ Kompetensi Guru}

Kompetensi Guru; Kompetensi profesional guru menurut Sudjana (2002 : 1719, Anonim 2018) dapat dikelompokkan menjadi tiga bidang yaitu pedagogik, personal dan sosial. Kompetensi pedagogik menyangkut kemampuan intelektual seperti penguasaan mata pelajaran, pengetahuan menganai cara mengajar, pengetahuan mengenai belajar dan tingkah laku individu, pegetahuan tentang bimbingan penyuluhan, pengetahuan tentang administrasi kelas, pengetahuan tentang cara menilai hasil belajar, pengetahuan tentang kemasyarakatan serta pengetahuan umum lainnya.

Kompetensi bidang personal menyangkut kesiapan dan kesediaan guru terhadap berbagai hal yang berkenaan dengan tugas dan profesinya. Misalnya sikap menghargai pekerjaannya, mencintai dan memiliki perasaan senang terhadap mata pelajaran yang dibinanya, sikap toleransi terhadap sesama teman profesinya, memiliki kemauan yang keras untuk meningkatkan hasil pekerjaannya.

Kompetensi sosial menyangkut kemampuan guru dalam berbagai ketrampilan/berperilaku, seperti ketrampilan mengajar, membimbing, menilai, menggunakan alat bantu pengajaran, bergaul atau berkomunikasi dengan siswa, ketrampilan menumbuhkan semangat belajar para siswa, ketrampilan menyusun persiapan/ perencanaan mengajar, ketrampilan melaksanakan administrasi kelas, dan lainlain. Perbedaan dengan kompetensi kognitif terletak pada sifatnya. Kompetensi kognitif berkenaan dengan aspek teori atau pengetahuannya, pada kompetensi perilaku yang diutamakan adalah praktek/ketrampilan melaksanakannya.

Berdasarkan Peraturan Pemerintah Nomor 19 Tahun 2005 tentang Standar Nasional Pendidikan, guru harus memiliki kompetensi pedagogik, kepribadian, profesional, dan sosial (Depdiknas, 2005:24, 90-91, Anonim 2018).

1. Kompetensi pedagogik merupakan kemampuan yang berkenaan dengan pemahaman peserta didik dan pengelola pembelajaran yang mendidik dan dialogis. Secara substantif kompetensi ini mencakup kemampuan pemahaman terhadap peserta didik, perancangan dan pelaksanaan pembelajaran, evaluasi hasil belajar, dan pengembangan peserta didik untuk mengaktualisasikan berbagai potensi yang dimilikinya.

2. Kompetensi kepribadian merupakan kemampuan personal yang mencerminkan kepribadian yang yang mantap, arif, dewasa, dan berwibawa, menjadi teladan bagi peserta didik, dan berakhlak mulia.

3. Kompetensi profesional merupakan kemampuan yang berkenaan dengan penguasaan materi pembelajaran bidang studi secara luas dap mendalam yang mencakup penguasaan substansi isi materi kurikulum matapelajaran di sekolah dan substansi keilmuan yang menaungi materi kurikulum tersebut, serta menambah wawasan keilmuan sebagai guru.

4. Kompetensi sosial berkenaan dengan kemampuan pendidik sebagai bagian dari masyarakat untuk berkomunikasi dan bergaul secara efektif dengan peserta didik, sesama pendidik, tenaga kependidikan, orangtua/wali peserta didik, dan masyarakat sekitar. 
Yang dimaksud dengan kompetensi guru dalam penelitian tindakan sekolah (PTS) ini adalah kemampuan 6 (enam) guru dalam penyusunan Rencana Pelaksanaan Pembelajaran (RPP). Adapaun ciri-ciri RPP dikatakan baik dan benar adalah: 1) memuat aktifitas proses belajar mengajar yang akan dilaksanakan oleh guru dan menjadi pengalaman belajar bagi peserta didik, 2) langkah-langkah pembelajaran disusun secara sistematis agar tujuan pembelajaran dapat dicapai, 3) langkah-langkah pembelajaran disusun serinci mungkin, sehingga apabila RPP digandakan guru lain (misalnya, ketiga guru mata pelajaran tidak hadir) mudah dipahami dan tidak menimbulkan penafsiran ganda.

\section{Pendampingan}

Pendampingan adalah Upaya terus menerus dan sistematis dalam mendampingi (menfasilitasi) individu, kelompok maupun komunitas dalam mengatasi permasalahan dan menyesuaikan diri dengan kesulitan hidup yang dialami sehingga mereka dapat mengatasi permasalahan tersebut dan mencapai perubahan hidup ke arah yang lebih baik. Pendampingan merupakan proses interaksi timbal balik (tidak satu arah) antara individu/ kelompok/ komunitas yang mendampingi dan individu/ kelompok/ komunitas yang didampingi yang bertujuan memotivasi dan mengorganisir individu/ kelompok/ komunitas dalam mengembangkan sumber daya dan potensi orang yang didampingi dan tidak menimbulkan ketergantungan terhadap orang yang mendampingi (mendorong kemandirian). (Yayasan Pulih, 2011, Anonim 2018). Pendampingan dapat dilakukan dalam berbagai bentuk maupun situasi dengan pendekatan yang beragam baik formal maupun non formal, individu, kelompok maupun komunitas.

Pada dasarnya, konsep mentoring mencakup tiga komponen, yaitu: pendamping, yang terdampingi, dan proses pendampingan. Pendamping bisa seorang guru, sponsor, konselor, penasehat, teman sejawat, pendukung, orang kepercayaan, atau model. Yang terdampingi biasanya adalah seseorang yang masih pemula dan digambarkan sebagai mitra peserta dalam proses pendampingan. Proses pendampingan adalah pengembangan hubungan antara pendamping dan yang terdampingi. Definisi pendampingan sangat beragam tergantung pada strategi yang digunakan. Secara umum, pendampingan adalah proses yang melibatkan seseorang yang lebih berpengalaman, profesional, pakar untuk memberikan dukungan, bimbingan, dan nasehat kepada, serta berbagi pengalaman dengan rekan yang kurang berpengalaman.

Yang dimaksud dengan pendampingan dalam penelitian tindakan sekolah (PTS) ini adalah kepala SD Negeri 12 Ampenan selaku peneliti membimbing/mendampingi terhadap 6 (enam) guru sasaran dalam penyusunan RPP. Dalam pelaksanaannya pendampingan dilakukan melalui 2 (dua) tahapan. Tahap I semua guru dikumpulkan untuk mendapatkan penjelasan teknik tata cara penyusunan RPP sesuai dengan bidang studi/mata pelajaran yang diampunya. Tahap II yaitu pendampingan individual, dimana peneliti mendampingi secara individu dalam kelompok kecil untuk menjelaskan lebih rinci tata cara menyusun RPP

\section{Kelompok Kerja Guru (KKG)}

Trimo (2007: 12, Anonim 2018) Kelompok Kerja Guru yaitu suatu organisasi profesi guru yang bersifat struktural yang dibentuk oleh guru-guru di suatu wilayah atau gugus sekolah sebagai wahana untuk saling bertukaran pengalaman guna meningkatkan kemampuan guru dan memperbaiki kualitas pembelajaran.

Menurut Buchari Zainun 1987 (dalam, Suryosubroto 2004: 1, Anonim 2018) ada lima faktor yang mendasari kegiatan manusia dalam organisasi yaitu:

a. Faktor spesialisasi dan pembagian kerja;

b. Faktor koordinasi;

c. Faktor tujuan;

d. Faktor prosedur kerja;

e. Faktor dinamika lingkungan.

Sumadji (2013, Anonim 2018) menyatakan, "Kelompok Kerja Guru (KKG) bertujuan untuk menjadikan guru lebih profesional dalam upaya peningkatan mutu pendidikan”. Melalui pendekatan sistem 
pembinaan profesional diharapkan guru mampu merencanakan, melaksanakan, dan mengevaluasi kegiatan pembelajaran. Muhtadi (2008: 13, Anonim 2018) menyatakan, "Pembentukan KKG bertujuan untuk memfasilitasi kegiatan yang dilakukan di pusat kegiatan guru berdasarkan masalah dan kesulitan yang dihadapi guru, kemudian memberikan bantuan profesional kepada guru kelas dan mata pelajaran di sekolah, serta meningkatkan pemahaman, keilmuan, keterampilan dan pengembangan sikap profesional berdasarkan kekeluargaan dan saling mengisi (sharing)".

Menurut Standar Pengembangan KKG Derektorat Profesi Pendidik Direktorat Jendral Peningkatan Mutu Pendidikan dan Tenaga Kependidikan Departemen Pendidikan dan Kebudayaan Republik Indonesia, tujuan KKG adalah:

a. Memperluas wawasan dan pengetahuan guru dalam berbagai hal, khususnya penguasaan substansi materi pembelajaran, penyusunan silabus, penyusunan bahanbahan pembelajaran, strategi pembelajaran, metode pembelajaran, memaksimalkan pemakaian sarana/prasarana belajar, memanfaatkan sumber belajar, dsb

b. Memberikan kesempatan kepada anggota kelompok kerja atau musyawarah kerja untuk berbagi pengalaman serta saling memberikan bantuan dan umpan balik;

c. Meningkatkan pengetahuan dan keterampilan, serta mengadopsi pendekatan pembaharuan dalam pembelajaran yang lebih profesional bagi peserta kelompok kerja atau musyawarah kerja;

d. Memberdayaan dan membantu anggota kelompok kerja dalam melaksanakan tugas-tugas pembelajaran di sekolah;

e. Mengubah budaya kerja anggota kelompok kerja atau musyawarah kerja (meningkatkan pengetahuan, kompetensi dan kinerja) dan mengembangkan profesionalisme guru melalui kegiatankegiatan pengembangan profesionalisme di tingkat $\mathrm{KKG}$; f. Meningkatkan mutu proses pendidikan dan pembelajaran yang tercermin dari peningkatan hasil belajar peserta didik;

g. Meningkatkan kompetensi guru melalui kegiatan-kegiatan di tingkat KKG.

Yang dimaksud dengan kelompok kerja guru (KKG) dalam penelitian ini adalah 6 (enam) guru SD Negeri 12 Ampenan yang menjadi sasaran dalam pelaksanaan pendampingan dalam penyusunan RPP. Kegiatan nyata KKG SD Negeri 12 Ampenan yaitu penysunan Rencana Pelaksanaan Pembelajaran (RPP) yang dibimbing langsung oleh kepala sekolah selaku peneliti. Dalam kegiatan ini semua guru kelas dari kelas I sampai dengan guru kelas VI menyusun RPP secara individual dalam forum KKG. Kendala/kesulitan yang dialami oleh guru langsung diberikan bimbingan, perbaikan, dan penyempurnaansesuai dengan situasi dan kondisi pada saat KKG yang diselenggarakan di SD Negeri 12 Ampenan.

\section{Rencana Pelaksanaan Pendampingan (RPP)}

Pada hakekatnya penyusunan RPP bertujuan merancang pengalaman belajar siswa untuk mencapai tujuan pembelajaran. Tidak ada alur pikir (algoritma) yang spesifik untuk menyusun suatu RPP, karena rancangan tersebut seharusnya kaya akan inovasi sesuai dengan spesifikasi materi ajar dan lingkungan belajar siswa (sumber daya alam dan budaya lokal, kebutuhan masyarakat serta perkembangan ilmu pengetahuan dan teknologi). Pengalaman dari penilaian portofolio sertifikasi guru ditemukan, bahwa pada umumnya RPP guru cenderung bersifat rutinitas dan kering akan inovasi. Mengapa? diduga dalam melakukan penyusunan RPP guru tidak melakukan penghayatan terhadap jiwa profesi pendidik. Keadaan ini dapat dipahami karena, guru terbiasa menerima borang-borang dalam bentuk format yang mengekang guru untuk berinovasi dan penyiapan RPP cenderung bersifat formalitas. Bukan menjadi komponen utama untuk sebagai acuan kegiatan pembelajaran. Sehingga ketika otonomi pendidikan dilayangkan tak seorang gurupun bisa mempercayainya. Buktinya perilaku 
menyusun RPP dan perilaku mengajar guru tidak berubah jauh.

Acuan alur pikir yang dapat digunakan sebagai alternatif adalah:

1. Kompetensi apa yang akan dicapai.

2. Indikator-indikator yang dapat menunjukkan hasil belajar dalam bentuk perilaku yang menggambarkan pencapaian kompetensi dasar.

3. Tujuan pembelajaran yang merupakan bentuk perilaku terukur dari setiap indikator.

4. Materi dan uraian materi yang sesuai dengan kebutuhan belajar siswa agar ianya dapat mencapai tujuan pembelajaran.

5. Metode-metode yang akan digunakan dalam pembelajaran.

6. Langkah-langkah penerapan metodemetode yang dipilih dalam satu kemasan pengalaman belajar.

7. Sumber dan media belajar yang terkait dengan aktivitas pengalaman belajar siswa.

8. Penilaian yang sesuai untuk mengukur ketercapaian tujuan pembelajaran.

Secara umum, ciri-ciri Rencana Pelaksanaan Pembelajaran (RPP) yang baik adalah sebagai berikut:

1. Memuat aktivitas proses belajar mengajar yang akan dilaksanakan oleh guru yang akan menjadi pengalaman belajar bagi siswa.

2. Langkah-langkah pembelajaran disusun secara sistematis agar tujuan pembelajaran dapat dicapai.

3. Langkah-langkah pembelajaran disusun serinci mungkin, sehingga apabila RPP digunakan oleh guru lain (misalnya, ketiga guru mata pelajaran tidak hadir), mudah dipahami dan tidak menimbulkan penafsiran ganda.

\section{Prinsip-Prinsip Pengembangan RPP Menurut Kurikulum 2013}

Beberapa prinsip penting yang harus diperhatikan saat mengembangkan atau menyusun RPP adalah sebagai berikut.

1. RPP disusun oleh guru sebagai terjemahan dari ide kurikulum dan berdasarkan silabus yang telah dikembangkan di tingkat nasional ke dalam bentuk rancangan proses pembelajaran untuk direalisasikan dalam pembelajaran. Jadi dalam hal ini guru harus mampu menterjemahkan ide-ide yang dimuat dalam Kurikulum 2013. Penterjemahan ide-ide didasarkan pada silabus yang telah disiapkan oleh pemerintah pusat dalam hal ini departemen pendidikan dan kebudayaan. Kemampuan menterjemahkan ide akan terlihat saat guru mengembangkan RPP dan menyesuaikan apa yang dinyatakan dalam silabus dengan kondisi di satuan pendidikan baik kemampuan awal peserta didik, minat, motivasi belajar, bakat, potensi, kemampuan sosial, emosi, gaya belajar, kebutuhan khusus, kecepatan belajar, latar belakang budaya, norma, nilai, dan/atau lingkungan peserta didik.

2. RPP yang dibuat selalu mengedepankan perencanaan pembelajaran yang nantinya dalam proses belajar mengajar akan mendorong partisipasi aktif siswa. RPP yang dibuat tidak boleh menyimpang dari tujuan Kurikulum 2013 yaitu untuk menghasilkan siswa sehingga menjadi manusia yang mandiri dan tak berhenti belajar (pebelajar sepanjang hayat/lifelong learner), proses pembelajaran yang berpusat pada siswa (student centered) sehingga dapat mengembangkan motivasi, minat, rasa ingin tahu (curiousity), kreativitas, inisiatif, inspirasi, kemandirian, semangat belajar, keterampilan belajar dan kebiasaan belajar.

3. Pengembangan RPP yang baik akan mengedepankan proses pembelajaran yang mengembangkan budaya membaca dan menulis pada diri peserta didik. Proses pembelajaran dalam RPP dirancang untuk mengembangkan kegemaran membaca, pemahaman beragam bacaan, dan berekspresi dalam berbagai bentuk tulisan.

4. Di dalam RPP terdapat cara-cara dan langkah-langkah yang dapat dilakukan oleh guru untuk memberikan umpan balik (feedback) dan tindak lanjut (follow up). RPP memuat rancangan program pemberian umpan balik positif (positive feedback), penguatan (reinforcement), 
pengayaan (enrichment), dan remedi. Pemberian pembelajaran remedi harus dilakukan guru setiap saat setelah suatu ulangan atau ujian dilakukan, hasilnya dianalisis, dan kelemahan setiap peserta didik dapat teridentifikasi. Pemberian pembelajaran diberikan sesuai dengan kelemahan peserta didik.

5. Perancangan RPP memperhatikan keterkaitan dan keterpaduan antara materimateri pembelajaran yang satu dengan materi pembelajaran yang lainnya. RPP harus sedemikian rupa sehingga keterkaitan dan keterpaduan antara KI dan $\mathrm{KD}$, materi pembelajaran, kegiatan pembelajaran, penilaian, dan sumber belajar menjadi satu kesatuan utuh berbentuk pengalaman belajar yang bermakna bagi siswa. RPP disusun dengan mengakomodasikan pembelajaran tematik, keterpaduan lintas matapelajaran untuk sikap dan keterampilan, dan keragaman budaya.

6. Menerapkan teknologi informasi dan komunikasi. RPP disusun dengan mempertimbangkan penerapan teknologi informasi dan komunikasi secara terintegrasi, sistematis, dan efektif sesuai dengan situasi dan kondisi.

\section{Komponen dan Sistematika RPP}

RPP pada Kurikulum 2013 paling sedikit memuat: (i) tujuan pembelajaran, (ii) materi pembelajaran, (iii) metode pembelajaran, (iv) sumber belajar, dan (v) penilaian.

Komponen-komponen tersebut secara operasional diwujudkan dalam bentuk format RPP Kurikulum 2013 berikut ini.

\section{Kerangka Konseptual}

Variabel harapan dalam penilaian ini adalah meningkatnya kompetensi 6 (enam) guru sasaran dalam penyusunan RPP, sedangkan variabel tindakan dalam penelitian iniadalah melaksanakan pendampingan secara klasikal (kelompok besar) dan pendampingan individual (kelompok kecil/perorangan) berbasis Kelompok Kerja Guru (KKG).
“ jika pendampingan berbasis $\mathrm{KKG}$ dilaksanakan dengan baik, maka kompetensi guru dalam penyusunan RPP di SD Negeri 12 Ampenan semester dua Tahun Pelajaran 2018/2019 dapat di tingkatkan”

\section{PROSEDUR PENELITIAN \\ Jenis Tindakan \\ Setting Penelitian}

Penelitian Tindakan Sekolah (PTS) ini dilaksanakan di SD Negeri 12 Ampenan yang pelaksanaannya melalui kegiatan pendampingan berbasis KKG bagi 6 (enam) guru sasaran dalam penyusunan RPP yang dilaksanakan dalam forum KKG sekolah

\section{Jenis Tindakan dan Dampak yang diharapkan}

- Jenis Tindakan: pendampingan berbasis KKG dalam penyusunan RPP bagi 6 (enam) guru sasaran di SD Negeri 12 Ampenan semester dua Tahun Pelajaran 2018/2019

- Dampak yang diharapkan : Meningkatnya kompetensi 6 (enam) guru sasaran dalam penyusunan RPP.

\section{Perencanaan Tindakan}

\section{Jenis tindakan yang dilakukan}

1. Kepala sekolah menginformasikan hasil pantauan, supervisi administrasi terhadap 6 (enam) guru sasaran bahwa guru-guru dimaksud masih belum mampu/mengalami kendala/hambatanhambatan dalam penyusunan RPP.

2. Kepala sekolah menyampaikan perlunya diadakanpendampingan berbasis KKG bagi guru sasaran dalam penyusunan RPP

3. Kepala Sekolah menyampaikan materi pendampingan sesuai dengan skenario pelaksanaan pendampingan berbasis KKG. Untuk mendapatkan gambaran riil tentang skenario pelaksanaan tindakan pada kegiatan pendampingan berbasis KKG ini dapat di gambarkan sebagai berikut:

\section{Hipotesis Tindakan}




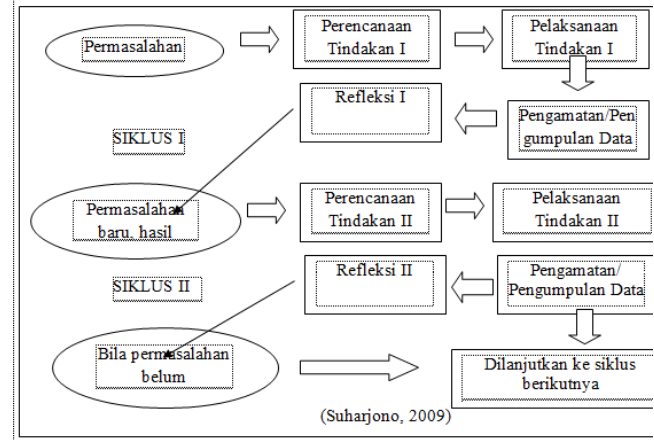

\section{Pelaksanaan Tindakan}

Pelaksanaan tindakan yang meliputi deskripsi tindakan yang dilakukan meliputi pelaksanaan rencana tindakan yang telah disiapkan, termasuk didalamnya langkahlangkah pelaksanaan atau praktik kepengawaasan di sekolah dalam setiap siklus (Suharjono, 2009). Dalam kegiatan ini peneliti melakukan kegiatan pendampingan penyusunan Rencana Pelaksanaan Pembelajaran (RPP) yang baik dan benar dengan berpedoman pada perencanaan pendampingan yang telah di tetapkan.

\section{Evaluasi dan Refleksi Tindakan}

Pada tahapan ini peneliti melakukan kajian dan penelitian proses tindakan dan hasil atau dampak tindakan terhadap perubahan perilaku sasaran (nana Sujana, 2009:39). Adapun kegiatan riilnya adalah: 1) membandingkan hasil pengamatan pelaksanaan kerja kelompok/diskusi yang difokuskan kegiatan penyusunan RPP, 2) membandingkan hasil kerja individual dari 6 (enam) guru sasaran dalam penyusunan RPP dengan indikator keberhasilan yang telah ditetapkan.

\section{Siklus Tindakan}

Dalam penelitian ini di rencanakan sebanyak 2 (duaa) siklus, masing-masing siklus 1 (satu) kali pertemuan dengan agenda 2 (dua) kegiatan secara terpadu yaitu pendampingan klasikal/kelompok besar dan pendampingan individual/kelompok kecil. Pada kegiatan pendampingan secara klasikal peneliti menyampaikan materi tentang tata cara menyusun RPP yang baik dan benar dilanjutkan dengan kerja kelompok/diskusi kelompok. Kegiatan masing-masing siklus terdiri dari 4 (empat) tahapan yaitu perencanaan, pelaksanaan, observasi, dan refleksi. Untuk mendapatkan gambaran secara rinci kegiatan masing-masing tahapan dapat di jelaskan sebagai berikut:

\section{SIKLUS I}

\section{Tahap I : Perencanaan Tindakan}

1.1. Menyusun materi pendampingan

1.2. Menetapkan scenario dan langkahlangkah pendampingan yang tertuang dalam Rencana Pelaksanaan pendampingan (RPP)

1.3. Menyusun instrument observasi kepala sekolah dan observasi guru

1.4. Menentukan jadwal kegiatan pendampingan

1.5. Menyusun pedoman analisa data hasil observasi dan tugas individu.

Tahap II. Pelaksanaan Tindakan

Pada kegiatan pendampingan secara berkelompok yang kegiatannya adalah :

2.1. Menyampaikan materi tentang tata cara penyusunan RPP.

2.2. Melaksanakan diskusi kelompok kecil dalam penyusunan RPP.

2.3. Memberikan bimbingan secara berkelompok/perorangan.

2.4. Memberikan solusi terhadap permasalahan yang dihadapi oleh guru

2.5. Memberikan penguatan/reward

2.6. Memberikan tugas individual.

$$
\text { Pada kegiatan pendampingan }
$$

individual yang dilakukan secara bergiliran, dengan cara peneliti mendekati guru satu persatu dalam kelompok untuk membimbing secara individual agar permasalahanppermasalahan dapat dipecahkan dengan baik dan benar.

\section{Tahap III. Observasi/pengumpulan Data}

3.1. Pengamatan terhadap aktifitas guru peserta pendampingan

3.2. Pengamatan terhadap kinerja guru dalam penyusunan RPP.

3.3. Menilai hasil kerja guru secara individual

\section{Tahap IV. Refleksi}

4.1. Renungan atas data hasil observasi dan hasil kerja secara individual.

4.2. Pengolahan data hasil penelitian dan mencocokkan dengan indikator keberhasilan.

4.3.Rencana perbaikan dan penyempurnaan 
4.4. Memberikan penguatan atas hasil yang diperolehnya.

4.5. Rencana tindak lanjut.

\section{SIKLUS II}

Jenis kegiatan pada siklus II ini pada dasarnya sama dengan siklus $\mathrm{I}$, bedanya hanya terjadi perbaikan/penyempurnaan dalam pelaksanaannya.

\section{Indikator Keberhasilan}

1. Hasil observasi kepala sekolah maupun observasi guru peserta pendampingan telah mencapai skor rata-rata $\geq 4,0$ (Kategori baik).

2. Hasil kerja secara individual penyusunan RPP dinyatakan telah berhasil jika mencapai $\geq 85 \%$ dengan nilai rata-rata $\geq$ 80,00 (Kategori Baik).

\section{LAPORAN HASIL DAN PEMBAHASAN \\ Laporan Hasil \\ Deskripsi Siklus I \\ Tahap Perencanaan}

Pada tahapan ini peneliti melakukan:

1) menyusun materi pendampingan, 2) menetapkan skenario dan langkah-langkah pendampingan yang tertuang dalam Rencana Pelaksanaan Pendampingan (RPP), 3) menyusun instrumen observasi kepala sekolah dan instrumen observasi guru, 4) menentukan jadwal kegiatan pendampingan, 5) menyusun pedoman analisis data

\section{Tahap Pelaksanaan}

- Pendampingan klasikal/kelompok; 1) menyampaikan materi tentang tata cara penyusunan RPP, 2) melaksanakan diskusi kelompok kecil dalam penyusunan RPP, 3) memberikan bimbingan secara berkelompok, 4) memberikan solusi terhadap permasalahan yang dihadapi oleh guru, 5) memberikan penguatan/reward, dan 6) memberikan tugas individual.

- Pendampingan individual, jenis kegiatannya adalah; 1) pada saat guru bekerja dalam kelompok/diskusi kelompok peneliti membimbing guru yang mengalami kesulitan dalam penyusunan RPP secara kelompok kecil/perorangan, 2) memberikan solusi/pemecahan terhadap kesulitan yang dirasakan secara individual, 3) kegiatan seterusnya sampai ke 6 (enam) guru peserta pendampingan mendapatkan giliran pendampingan secara individual

\section{Tahap Observasi}

Observasi kepala sekolah memperoleh skor rata-rata sebesar 3,40, observasi guru memperoleh skor rata-rata sebesaar 3,33 dan perolehan hasil individu memperoleh nilai rata-rata sebesar 67,40

\section{Tahap Refleksi}

Pada tahapan ini peneliti merenung atas perolehan data hasil observasi kepala sekolah, observasi guru, dan nilai individual hasil penyusunan RPP. Selanjutnya peneliti mengolah data dan hasilnya di cocokkan dengan indikator keberhasilan. Karena perolehan hasil masih dibawah indikator keberhasilan yang direncanakan, maka pada siklus berikutnya akan diadakan perbaikan dan penyempurnaan dari serangkaian kegiatan pendampingan secara klasikal maupun secara individual, namun demikian peneliti tetap memberikan penguatan atas hasil yang diperolehnya dan penelitian dilanjutkan pada siklus II dengan mengoptimalkan semua jenis tindakan dalam pendampingan sehingga di peroleh hasil yang memuaskan.

\section{Deskripsi Siklus II \\ Tahap Perencanaan}

Tahapan perencanaan pada siklus II jenis kegiatannya masih sama dengan siklus I, bedanya pada siklus II ini lebih memfokuskan perbaikan/penyempurnaan dalam proses pendampingan klasikal maupun pendampingan individual, yang jenis kegiatannya adalah: 1) menyempurnakan materi pendampingan, 2) menetapkan skenario pendampingan, 3) menetapkan instrumen observasi kepala sekolah maupun observasi guru, 4) menetapkan jadwal kegiatan pendampingan, 5) menyusun pedoman analisis data hasil observasi dan tugaas individu

\section{Tahap Pelaksanaan}

- Pendampingan klasikal/kelompok; 1)menyampaikan/merefleksi hasil perolehan data pada siklus I, 2) menjelaskan ulang tata cara penyusunan RPP secara lebih rinci, 3) perbaikan RPP secara berkelompok/diskusi kelompok, 4) memberikan refleksi terhadap hasil kerja 
kelompok yang mengalami kendala, 5) memberikan penghargaan/reward dan 6) memberikan tugas individual.

- Pendampingan individual/kelompok kecil; 1) pada saat proses kerjasama dalam kelompok, peneliti mengamati/mencermati hasil kerja secara individual, 2) memberikan bimbingan/merefleksi terhadap hasil kerja individual yang masih mengalami kendala, 3) begitu seterusnya sampai semua guru peserta pendampingan mendapatkan pendampingan secara individual.

\section{Tahap Observasi/Pengumpulan Data}

Observasi kepala sekolah memperoleh skor rata-rata sebesar 4,50, observasi guru memperoleh skor rata-rata sebesaar 4,67 dan perolehan hasil individu memperoleh nilai rata-rata sebesar 87,37

\section{Tahap Refleksi}

Pada tahapan ini peneliti merenung atas perolehan data hasil observasi kepala sekolah, observasi guru, dan nilai individual hasil penyusunan RPP. Kemudian di olah engan menggunakan rumus yang telah ditetapkan. Karena perolehan hasil siklus II sudah melebihi indikator keberhasilan, maka tidak perlu ada perbaikan/penyempurnaan dalam penyusunan RPP, selanjutnya peneliti memberikan penghargaan/reward kepada semua guru peserta pendampingan karena dari 6 (enam) guru sasaran $100 \%$ sudah memperoleh nilai rata-rata $\geq 80,00$. Penelitian dinayatakan berhasil dan tindakan dihentikan pada siklus II.

\section{Pembahasan}

\section{SIKLUS I}

\section{Tahap Perencanaan}

Dalam penyusunan materi pendampingan, menetapkan skenario dan langkah-langkah pendampingan, dan perencanaan penyusunan instrumen observasi kepala sekolah dan instrumen observasi guru peneliti mengalami beberapa kendala yaitu dalam pendampingan klasikal maupun pendampingan individual. Faktor penyebabnya adalah karena peneliti masih belum menemukan strategi yang tepat dan diterima oleh peserta. Solusi yang dilakukan oleh peneliti adalah dengan meminta petunjuk dari pengawas pembimbing, sekolah diberikan petunjuk dan arahan nyata maka pendampingan klasikal dan individualpun terlaksana dengan baik.

\section{Tahap Pelaksanaan}

Kegiatan nyata dalam pelaksanaan pendampingan dapat dijabarkan sebagai berikut: pada saat menyampaikan materi tentang tata cara penyusunan RPP mengalami kendala yang disebabkan peneliti masih kekurangan sumber/buku literatur, sehingga berdampak tertundanya dalam penyusunan, solusi yang dilakukan peneliti mencari beberapa buku literatur terkait dengan tata cara penyusunan RPP termasuk mencari di internet, akhirnya materi pendampingan dapat tersusun dengan baik. Dalam pelaksanaan bimbingan pada saat peserta pendampingan melakukan diskusi/kerjasama dalam kelompok, peneliti berkeliling memberikan bimbingan dan solusi terhadap peserta yang mengalami kesulitan. Pada kegiatan ini peneliti tidak mengalami hambatan/permasalahan artinya berjalan sesuai dengan rencana.

\section{Tahap Observasi/Pengumpulan Data}

Hasil perolehan skor selama pendampingan pada siklus I peneliti memperoleh skor rata-rata $(3,40)$ dari indikator keberhasilan yang direncanakan yaitu $\geq 4,0$. Ini artinya peneliti masih belum berhasil membimbing 6 (enam) guru peserta pendampingan. Perolehan skor rata-rata aktifitas peserta pendampingan pada siklus I yaitu $(3,33)$ dari indikator keberhasilan $(\geq 4,0$ ). Perolehan nilai rata-rata hasil kerja guru dalam penyusunan RPP secara individual memperoleh rata-rata $(67,40)$ dari indikator keberhasilan $\geq 80,0$ (kategori baik). Dari 6 (enam) guru peserta pendampingan pada siklus I belum ada satu guru pun yang dinyatakan memperoleh nilai rata-rata $\geq$ 80,00. Ini artinya pada siklus I presentasi pencapaian hasil kerja individual masih $0 \%$, dalam arti belum ada yang tuntas sesuai indikator yang telah ditetapkan. Pada kegiatan siklus berikutnya peneliti harus mampu memotivasi peserta pendampingan dalam upaya mencapai indikator keberhasilan 
sebagai dampak nyata dari hasil pendampingan.

\section{Tahap Refleksi}

Perolehan skor rata-rata hasil observasi kepala sekolah selama proses pendampingan baru memperoleh skor ratarata $(3,40)$, sementara perolehan hasil observasi peserta pendampingan sebagai aktifitas peserta selama pendampingan baru memperoleh skor rata-rata $(3,33)$, dan nilai rata-rata hasil penyusunan RPP baru mencapai nilai rata-rata $(67,40)$. Dari perolehan hasil dimaksud peneliti merenung mencari faktor kendala dan penyebab sehingga hasil masil belum optimal. Dari hasil renungan itu akhirnya peneliti menemukan solusi untuk dapat dilaksanakan pada kegiatan pendampingan siklus berikutnya.

\section{SIKLUS II}

\section{Tahap Perencanaan}

Kesalahan-kesalahan yang terjadi pada siklus I sudah diperbaiki pada siklus II, sehingga pada tahapan ini peneliti bisa melakukan dengan baik. Kegiatan pada tahap perencanaan ini meliputi; 1) penyempurnaan penyusunan materi pendampingan, 2) perbaikan skenario/strategi/langkah-langkah pendampingan yang mengarah kepada peserta aktif, 3) menetapkan instrumen observasi kepala sekolah dan instrumen observasi guru, 4) menentukan jadwal kegiatan dan menetapkan pedoman analisa data hasil observasi dan hasil kerja individual.

\section{Tahap Pelaksanaan}

Pada tahapan ini, peneliti terlebih dahulu melakukan refleksi atas capaian hasil yang diperoleh pada siklus I. Kendala-kendala dan permasalahan yang terjadi dibahas sampai semua peserta pendampingan memahami dan menyadari akan kekurangan, kesalahan dan hal-hal yang bersifat krusial dapat dipecahkan pada saat kegiatan refleksi.

Kegiatan selanjutnya peneliti menyampaikan materi pendampingan secara perlahan-lahan, ringkas dan jelas sehingga peserta pendampingan lebih paham dan mengerti tata cara penyusunan RPP. Pelaksanaan diskusi kelompok dioptimalkan,

\section{Tahap Observasi}

Pada siklus II perolehan skor rata-rata hasil observasi kepala sekolah adalah $(4,50)$ dari indikator keberhasilan $\geq 4,00$, ini artinya menunjukkan peningkatan yang sangat signifikan bila dibandingkan dengan perolehan hasil pada siklus I. Skor rata-rata hasil observasi guru yaitu aktifitas selama pendampingan dalam forum $\mathrm{KKG}$ memperoleh skor rata-rata $(4,67)$ dari indikator keberhasilan $\geq 4,00$. Dari hasil ini nampak nyata bahwa aktifitas peserta pendampingan pada siklus II mengalami peningkatan yang sangat tajam karena sudah mampu melampaui indikator keberhasilan yang telah ditetapkan. Nilai rata-rata hasil kerja individual dalam penyusunan RPP yakni $(87,37)$ dari indikator keberhasilan $(\geq 80,00)$.

\section{Tahap Refleksi}

Karena semua indikator keberhasilan telah tercapai maka penelitian tindakan sekolah dihentikan pada siklus II dan dinyatakan berhasil memotivasi guru untuk lebih bergairah dan lebih bersemangat dalam upaya penyusunan RPP. Penelitian Tindakan Sekolah dengan judul "Melaksanakan Pendampingan Berbasis KKG Bagi Guru Kelas SD Negeri 12 Ampenan Semester Dua Tahun Pelajaran 2018/2019 Upaya Meningkatkan Kompetensi Guru Dalam Penyusunan Rencana Pelaksanaan Pembelajaran (RPP)", dinyatakan "BERHASIL"

\section{Kesimpulan}

Pelaksanaan pendampingan berbasis KKG terbukti sangat efektif dalam upaya meningkatkan kompetensi guru kelas dalam penyusunan RPP di SSD Negeri 12 Ampenan. Hal ini dapat dilihat data riil peningkatan kompetensi guru dari siklus I ke siklus II.

Adapun perolehan skor/nilai selama penelitian dapat dipaparkan sebagai berikut:

\begin{tabular}{|c|c|c|c|c|c|}
\hline \multirow[b]{2}{*}{ No } & \multirow[b]{2}{*}{ Jenis Keggintan } & \multirow[b]{2}{*}{$\begin{array}{l}\text { Indikator } \\
\text { Keberilasilan }\end{array}$} & \multicolumn{2}{|c|}{ Peroletan } & \multirow[b]{2}{*}{ Ket } \\
\hline & & & $\begin{array}{c}\text { Siklus } \\
\text { I }\end{array}$ & $\begin{array}{c}\text { Siklus } \\
\text { II }\end{array}$ & \\
\hline 1. & Hasil Observasi Kepala Sekolah & 24,00 & 3,40 & 4,50 & Meningkat \\
\hline 2. & Hasil ObservasíGunu & 24,00 & 3,33 & 4,67 & Meningkat \\
\hline 3. & Hasil Kerja Individual & 380,00 & 67,40 & 87,37 & Meningkat \\
\hline
\end{tabular}


Indicator kinerja pada siklus II sudah tercapai maka Penelitian Tindakan Sekolah (PTS) dinyatakan "BERHASIL" dan dihentikan pada siklus II.

\section{Saran}

Disarankan kepada rekan kepala sekolah lain untuk melakukan pendampingan dengan semua guru mata pelajaran dibawah binaan pada sekolah masing-masing dalam upaya meningkatkan kompetensinya khususnya dalam penyusunan RPP yang bisa diterapkan dalam proses pembelajaran di kelas senyatanya. Dampak yang diharapkan yaitu meningkatnya kualitas/mutu peserta didik di sekolah binaan melalui proses pembelajaran yang dilandasi dengan penyusunan RPP.

Kepada seluruh guru SD Negeri 12 Ampenan disarankan untuk membiasakan melakukan musyawarah bersama dalam forum KKG mata pelajaran yang diampunya, khususnya dalam penyusunan RPP, sehingga berdampak meningkatnya kompetensi guru dalam proses pembelajaran di kelas senyatanya dan pada gilirannya prestasi belajar peserta didik dapat ditingkatkan.

\section{DAFTAR PUSTAKA}

Anonim, 2018, Definisi Pendampingan, dalam

https://kamuspsikososial.wordpress.co m/tag/definisi-pendampingan/, diakses tanggal 10 Juli 2018 Pukul 13.40 Wita

Anonim, 2018, Kompetensi Guru, dalam https://karyono1993.wordpress.com/th esis/kompetensi-guru/, diakses tanggal 11 Juli 2018 Pukul 11.00 wita

Anonim, 2018, Pengertian Kompetensi dan Kompetensi Guru, dalam https://mujibjee.wordpress.com/2010/ 01/11/pengertian-kompetensi-dankompetensi-guru/, di akses 15 Juli 2018 Pukul 12.45 wita

Anonim, 2018, Pengertian Pendampingan, dalam http://www.bintans.web.id/2010/12/pengertianpendampingan.html, diakses tanggal 10 Juli 2018 Pukul 13.40 Wita

Anonim, 2018, pengertian-tujuan-danmanfaat-kkg, dalam http://posnanggroe.com/2015/11/11/pe ngertian-tujuan-dan-manfaat-kkg/, diakses tanggal 7 Juli 2018, pukul 15.45 Wita

Irwan sahaja , 2018, Pengertian Kelompok Kerja Guru, dalam http://irwansahaja.blogspot.co.id/2014/ 08/pengertian-kelompok-kerja-gurukkg.html, diakses tanggal 8 Juli 2017, pukul 12.30 Wita

Kementrian Pendidikan Nasional, 2010, Kepemimpinan Pembelajaran, Dirjen PMPTK

Keputusan Mentri Pendidikan Nasional No. 16 Tahun 2007, Standar Kualifikasi Akademik dan Kompetensi Guru.

Nana Sujana, 2009, Pendidikan Tingkat KePenelitian Konsep Dan Aplikasinya Bagi Peneliti Sekolah, Jakarta: LPP Bina Mitra.

Peraturan Pemerintah No. 19 tahun 2005 tentang Standar Nasional Pendidikan

Purnadi Pungki, M.W., 2009, KompetensiFaktor Kunci Keberhasilan, dalam http://vibizconsulting.com. Diakses tanggal 11 Agustus 2015 pukul 19.35 wita

Suharjono, 2009, Melaksanakan Sekolah Sebagai Kegiatan Penelitian Tindakan Sekolah Sebagai Kegiatan Pengembangan Profesi Penelitia Sekolah, Jakarta: Bumi Aksara.

Suharjono, 2012, Publikasi Ilmiah Dalam Kegiatan Pengembangan Keprofesian Berkelanjutan Bagi Guru, Jakarta: Cakrawala Indonesia.

Undang-Undang Republik Indonesia, No. 14 Tahun 2005, Guru dan Dosen Daftar Pustaka

Winsolu, 2009, Pengertian Kompetensi, dalam http://my.opera.com/winsolu/blog/pen gertian-kompetensi Diakses tanggal 11 Agustus 2015 pukul 19.35 wita 